\title{
Al-Mabadi' Al-Khamsah dan Al-Kulliyah Al-Khams; Sebagai Konsep Penjamin Hak Kebebasan Beragama Berkeyakinan
}

\author{
Muhammad Isnan ${ }^{1}$, Moch. Mukhlison ${ }^{2}$ \\ 12 Institut Agama Islam Tribakti (IAIT) Kediri Indonesia \\ 1isnanelsam@gmail.com,2moch.mukblison89@gmail.com
}

\begin{abstract}
The case of intolerance and restrictions on the right to religious freedom is a neverending discourse. That is because these cases still occur in Indonesia with such high numbers. In the last five years, data shows an increase in cases of intolerance and restrictions on religious freedom. In this condition, it turns out that the right to freedom of religion and belief has not provided benefits for minority groups. This paper tries to reveal how the rights to freedom of religion and belief are upheld by the norms of Human Rights and the State as the guarantor. This article also tries to reveal that even Islam with the teachings of tolerance and the concept of Al-Mabadi 'Al-Khamsah and AlKulliyah Al-Khams provide support for the creation of justice, peace and harmonious relations between humans.
\end{abstract}

Keywords: Al-Mabadi' Al-Khamsah, Al-Kulliyah Al-Khams, Right to Freedom of Religion and Belief.

\begin{abstract}
Abstrak
Kasus intoleransi dan pembatasan hak kebebasan beragama menjadi diskursus yang tidak kunjung usai. Demikian, karena kasus itu masih saja terjadi di Indonesia dengan angka yang begitu tinggi. Di lima tahun terakhir, data menunjukkan adanya peningkatan terjadinya kasus intoleransi dan pembatasan kebebasan beragama. Dalam kondisi tersebut, ternyata hak kebebasan beragama dan berkeyakinan belum memberikan manfaat untuk kelompok minoritas. Tulisan ini mencoba untuk mengungkap bagaimana hak kebebasan beragama dan berkeyakinan itu di junjung norma Hak Asasi Manusia dan Negara sebagai penjaminnya. Artikel ini juga mencoba mengungkap bahwa Islam pun dengan ajaran toleransi dan konsep Al-Mabadi' Al-Khamsah dan Al-Kulliyah Al-Khams memberikan dukungan demi terciptanya keadilan, kedamaian, dan hubungan harmonis antar umat manusia.
\end{abstract}

Kata Kunci: Al-Mabadi' Al-Khamsah, Al-Kulliyah Al-Khams, Hak Kebebasan Beragama dan Berkeyakinan.

\section{Pendahuluan}

Tahun lalu, Seperti yang dicatat oleh KontraS pada akhir tahun 2020, masih terjadi 48 kasus tindakan intoleran dan pembatasan kebebasan beragama, beribadah dan berkeyakinan. ${ }^{1}$ Peristiwa tersebut terjadi di 17 provinsi di Indonesia, paling banyak terjadi di Jakarta Barat sebanyak 10 kali. Sedangkan, data skor indeks yang dicatat oleh Setara Institut pada 2020 kasus pelanggaran HAM secara umum telah mengalami penurunan. Namun dalam hal hak kebebasan beragama/berkeyakinan, PBM No. 9 dan 8 Tahun 2006 masih menjadi faktor kuat banyaknya konflik pendirian rumah ibadah di masyarakat. Dalam catatan Setara Institute diskriminasi terhadap kelompok agama dan kepercayaan juga masih

${ }^{1}$ Fatia Maulidiyanti, "Catatan Hari HAM 2020: HAM dalam Bayang-Bayang Otoritarianisme," Tahunan, Cahaham 2020 (KontraS, 2020), 8

Jurnal Kopis: Kajian Penelitian dan Pemikiran Komunikasi Penyiaran Islam

Volume 03, Issue 02, Februari 2021 
banyak dijumpai mulai dari penyegelan masjid Al-Aqso milik Jemaat Ahmadiyah di Kampung Bedakpaeh, Tasikmalaya hingga kasus intoleran penyerangan terhadap acara peristiwa midodareni salah seorang putri dari keluarga penganut Syiah yaitu Habib Umar Assegaf yang berujung pada korban luka. Gangguan terhadap kegiatan peribadatan juga menjadi penambah deretan kasus pelanggaran kebebasan beragama, seperti yang terjadi terhadap jemaat HKBP Kota Bekasi pada 13 September 2020. Pasifnya Forum Kerukunan Umat Beragama (FKUB) dalam membangun dialog dan komunikasi antar agama juga mempengaruhi masih masifnya intoleransi. ${ }^{2}$

Sampai saat ini, aksi-aksi kekerasan berbasis agama semakin marak dan terjadi begitu saja tanpa kawalan. Tidak ada usaha pencegahan, pendampingan, apalagi penanganan yang serius oleh negara. Lihat saja, kasus pembubaran ibadah kebaktian Natal di Sabuga, Bandung. Dilanjutkan pembongkaran masjid Jamaah Ahmadiyah Indonesia (JAI) di Kendal. Pengusiran JAI di Bangka. Pembakaran pemukiman eks anggota Gafatar di Kalimantan. Pelarangan pendirian gereja di berbagai daerah, dan masih banyak lagi lainnya.

Semua kasus-kasus tersebut terus terjadi seakan baik-baik saja. Semuanya berjalan tanpa pernah dipersoalkan. Padahal, jelas-jelas berbagai kasus di atas merupakan aksi yang bertentangan dengan hak kebebasan beragama. Hak ini secara jelas dipaparkan dalam pasal 28E Undang-Undang Dasar (UUD) 1945 ayat (1) yang berbunyi: "setiap orang bebas memeluke agama dan beribadat menurut agamanya, memilib pendidikan dan pengajaran, memilib pekerjaan, memilih kewarganegaraan, memilih tempat tinggal di wilayah negara dan meninggalkannya, serta berbake kembali". ${ }^{3}$ Kemudian dipertegas lagi dalam pasal 28E UUD 1945 ayat (2) bahwa setiap orang berhak atas kebebasan meyakini kepercayaan.

Meskipun sudah secara jelas disebutkan bahwa setiap orang mempunyai hak kebebasan beragama, lagi-lagi Negara sampai saat ini tidak melaksanakan tanggung jawabnya dalam melindungi (to protect) kelompok yang menjadi korban dari serangan dan pemberangusan hak kebebasan beragama/berkeyakinan. Dalam hal ini, seharusnya Negara bersifat aktif untuk melindungi kelompok rentan. Namun nyatanya negara masih saja bersikap pasif untuk menangani kasus-kasus ini. Negara telah gagal melaksanakan pasal 29 ayat (2) bahwa negara menjamin kemerdekaan tiap-tiap penduduknya untuk memeluk agama.

Setelah dua tahun pemerintahan Jokowi, belum satu pun kasus-kasus pelanggaran hak kebebasan beragama yang mendapatkan perhatian, apalagi penyelesaian sampai tuntas. Kasus-kasus tersebut masih menggantung. Pelanggaran hak kebebasan beragama kelompok kepercayaan di berbagai wilayah masih merajalela. Maraknya hate speech bernuansa agama dibiarkan begitu saja. Juga kelahiran sejumlah regulasi agama yang diskriminatif di berbagai kota/kabupaten dan provinsi menunjukkan bahwa Jokowi tidak memberikan sumbangsih apa pun dalam hal penegakan hak kebebasan beragama/berkeyakinan.

\footnotetext{
${ }^{2}$ Sayyidatul Insiyah dan Ismail Hasani, "Regresi Hak Asasi di Tengah Pandemi: Executive Summary Indeks Kinerja HAM Tahun 2020,” Tahunan (Setara Institute, 2020), 4. Indonesia.

3 Republik Indonesia, "Undang-Undang Dasar Tahun 1945" (Lembaran Negara RI, 1945), Perpustakaan Nasional
} 
Hal ini tidak sesuai dengan janji-janji pasangan Jokowi-Kalla pada saat kampanye pemilihan presiden tahun 2014 silam. ${ }^{4}$ Dilanjut periode berikutnya kampanye pasangan calon presiden Joko Widodo dan KH Ma'ruf Amin juga memberi janji untuk menjunjung tinggi hak asasi manusia termasuk kelompok minoritas. Poin 7 dalam Misi Presiden JokowiKH Ma'ruf Amin disebut akan memberi perlindungan bagi segenap bangsa dan memberikan rasa aman pada seluruh warga ${ }^{5}$ tanpa memandang ras, agama, suku, dan golongan tertentu. Pasangan ini menyebutkan bahwa merebaknya intoleransi dan krisis kepribadian menjadi problem pokok bangsa yang harus segera diselesaikan. Jokowi juga secara tegas mengatakan bahwa perlunya peran negara dalam setiap konflik keagamaan dalam perlindungan kebebasan beragama bagi setiap warga negara. Sekarang, fakta menunjukkan sebaliknya. Sikap intoleransi semakin tumbuh subur di Indonesia, sebab Negara belum sepenuhnya melaksanakan fungsinya dalam menegakkan Hak Asasi Manusia (HAM).

\section{Metode}

Penelitian ini menggunakan metode penelitian pustaka atau studi library. Dengan begitu, data yang dikumpulkan adalah hasil perolehan dari buku-buku, laporan-laporan, catatan-catatan terkait dengan kebebasan beragama berkeyakinan di Indonesia. Terutama laporan yang ditulis oleh Lembaga KontraS dan Setara Institute yang selama ini konsentrasi dalam kasus-kasus intoleransi, terutama pada pelanggaran hak kebebasan beragama berkeyakinan. Selama tahun 2020, data utama diambil dari Catatan Tahunan KontraS yang berjudul Catatan Hari HAM 2020: HAM dalam Bayang-bayang Otoritarianisme dan laporan Setara Institute berjudul Regresi Hak Asasi di Tengah Pandemi: Executive Summary Indeks Kinerja HAM Tahun 2020. Dari data yang diperoleh keduanya saling melengkapi dan mengevaluasi.

\section{Hasil dan Pembahasan}

\section{Hukum Kebebasan Beragama dan Berkeyakinan}

Hak Asasi Manusia adalah hak yang dimiliki oleh manusia semata-mata karena mereka adalah manusia. Orang memilikinya bukan karena pemberian oleh masyarakat kepadanya atau berdasarkan hukum positif, tetapi hanya karena itu adalah martabat manusia. ${ }^{6}$ Dalam pengertian ini, meskipun setiap orang dilahirkan dengan warna kulit, jenis kelamin, bahasa, budaya, dan kebangsaan yang berbeda, dia tetap memiliki hak-hak tersebut. Inilah universalitas hak-hak ini. Selain bersifat universal, hak-hak ini juga tidak dapat dicabut. Artinya betapa pun buruknya perlakuan yang telah dijalani seseorang, atau betapa kejamnya perlakuan seseorang, ia tidak akan pernah berhenti menjadi manusia dan karenanya tetap memiliki hak-hak tersebut. Dengan kata lain, hak-hak ini adalah apa yang dia nikmati sebagai manusia.

\footnotetext{
${ }^{4}$ Tercatat sebanyak 41 halaman janji pasangan Joko Widodo - Jusuf Kalla, di antara janji manis itu ialah menawarkan program memasukkan pelajaran tentang HAM di sekolah, menyelesaikan kasus HAM masa lalu, dan merevisi UU Peradilan Militer. Kompas Cyber Media, "Ini Janji Jokowi-JK soal HAM," KOMPAS.com, diakses 25 Februari 2021, https://nasional.kompas.com/read/2014/05/21/1630112/Ini.Janji.Jokowi-JK.soal.HAM.

${ }^{5}$ Linda Hasibuan, "Menolak Lupa! Mau Dilantik, Ini Janji Kampanye Jokowi-Amin," news, diakses 25 Februari 2021, https://www.cnbcindonesia.com/news/20191020094552-4-108397/menolak-lupa-mau-dilantik-ini-janji-kampanye-jokowi-amin.

${ }^{6}$ Jack Donnelly, Universal Human Rights in Theory and Practice (Ithaca and London: Cornell University Press, 2013), 721.
}

Jurnal Kopis: Kajian Penelitian dan Pemikiran Komunikasi Penyiaran Islam

Volume 03, Issue 02, Februari 2021 
Ada dua instrumen HAM dalam menjamin hak kebebasan beragama dan berkeyakinan. Instrumen tersebut pertama adalah instrumen Internasional. Di dalamnya termasuk Deklarasi Universal Hak Asasi Manusia (DUHAM) dan ICCPR (International Covenant on Civil and Political Rights). Kedua, adalah instrumen Nasional yang merupakan instrumen hukum Nasional, dan di dalamnya termasuk konstitusi, UU No. 39 1999, dan juga UU No. 12 tahun 2005 sebagai ratifikasi dari ICCPR.

Berkaitan dengan Kebebasan beragama dan berkeyakinan, DUHAM pada pasal 18 menyebutkan bahwa "Setiap orang berbak atas kebebasan pikiran, hati nurani dan agama. Dalam hal ini termasuk kebebasan berganti agama atau kepercayaan, dan kebebasan untuk mewnjudkan agama atau kepercayaan dengan cara mengajarkannya, mempraktikekannya, melaksanakan ibadahnya dan menaatinya, baik sendiri maupun bersama-sama, dengan orang lain, di muka umum maupun di wilayah pribadi”. Kemudian dipertegas lagi pada ICCPR pasal 18 ayat 1 dan 2.

(1) Setiap orang berbak atas kebebasan berpikir, berkeyakinan dan beragama. Hak ini meliputi kebebasan untuk memeluk suatu agama atau kepercayaan pilihannya sendiri, dan kebebasan menjalankan agama dan kepercayaannya baik secara sendiri maupun bersama-sama dengan orang lain, secara terbuka atau pribadi, dalam kegiatan ibadah, menaati, mengamalkan atau mengajarkannya.

(2) Kebebasan untuk menjalankan agama atau kepercayaan hanya dapat dikenai berbagai pembatasan yang ditentukan oleh bukum dan yang diperlukan untuk melindungi keselamatan, ketertiban, kesehatan ataupun moral umum, atau untuk melindungi hak-hak dan kebebasan orang lain.

Dalam hukum internasional di atas, sudah jelas bahwa setiap orang-tanpa membedakan ras, suku, golongan, atau apa pun - semua sama memiliki hak mutlak atas kebebasan beragama dan berkeyakinan yang tidak seorang pun dapat membatasi hak ini. Kecuali pembatasan ini melalui undang-undang yang tujuannya semata-mata hanya untuk menjamin pengakuan serta penghormatan terhadap hak dan kebebasan orang lain dengan syarat yang adil demi kesejahteraan umum.

Selanjutnya, telah diratifikasi oleh Indonesia pada Pasal 29 ayat (2) yang berbunyi, "Dalam menjalankan hak-hak dan kebebasan-kebebasannya, setiap orang harus tunduk hanya pada pembatasan-pembatasan yang ditetapkan oleb undang-undang yang tujuannya semata-mata untuk. menjamin pengakuan serta penghormatan yang tepat terhadap hak-bak dan kebebasan-kebebasan orang lain, dan untuk memenubi syarat-syarat yang adil dalam hal kesusilaan, ketertiban dan kesejabteraan umum dalam suatu masyarakat yang demokratis"

Berkaitan dengan hal ini, John Stuart Mill, yang dikutip oleh Adam Muhshi dalam bukunya "Teologi Konstitusi; Hukum Hak Asasi Manusia atas Kebebasan Beragama di Indonesia", Mill memberikan gagasan tentang "barm-principle". Gagasan ini bermaksud menegaskan bahwa, setiap orang bebas bertindak sesuka hatinya selama ia tidak mengganggu hak orang lain dengan tindakannya tersebut. Dalam artian, bahwa kebebasan tersebut tidak diberikan tanpa ada batasan dalam pelaksanaannya. Kebebasan tersebut terhenti manakala terdapat persinggungan. Persinggungan tersebut niscaya membatasi kebebasan seseorang agar tidak mengganggu atau merugikan hak dan kebebasan orang lain. ${ }^{7}$

\footnotetext{
${ }^{7}$ Muwaffiq Jufri, “Pembatasan terhadap Hak dan Kebebasan Beragama di Indonesia," Jurnal Ilmiah Pendidikan Pancasila dan Kewarganegaraan 1, no. 1 (2016): 42.

Jurnal Kopis: Kajian Penelitian dan Pemikiran Komunikasi Penyiaran Islam Volume 03, Issue 02, Februari 2021.
} 
Kalau dikaitkan dengan konteks kebebasan beragama, harm prinsiple ini mempunyai makna bahwa setiap orang bebas mengekspresikan keyakinannya selama tidak mengganggu atau merugikan hak keyakinan orang lain. Lebih dalam lagi, dalam konteks kebebasan beragama ini, sebenarnya terdiri dari dua unsur. Unsur keyakinan dan unsur manifestasi keyakinan. Asma Jahangir menyebutnya forum internum untuk keyakinan dan forum eksterum untuk manifestasinya. Forum internum menyangkut kebebasan beragama yang bersifat abstrak karena ada dalam lubuk hati dan sanubari manusia. Hanya manusia yang meyakini agama-agama yang mampu mendefinisikan keyakinan. Sedangkan forum eksternum lebih menyangkut hak kebebasan beragama yang bersifat kasat mata. Karena berupa perilaku keagamaan dalam bentuk ritual yang dimanifestasikan dari ajaran agama atau keyakinan tertentu. ${ }^{8}$

Dalam terminologi di atas, saya kira sama dengan apa yang diungkapkan oleh Hai'ah at-Tahrir dalam kitab al-mausu'ah al-islamiyah al-'ammah. At-Tahrir menyebutkan ada dua bentuk kebebasan. Pertama, ia sebut sebagai hurriyah dakbiliyah (kebebasan internal), yaitu kekuatan memilih antara dua hal yang saling bertentangan. Kedua, ia sebut sebagai burriyah kharijiyah (kebebasan eksternal) yaitu kekuatan yang menjadikannya mampu untuk melakukan sesuatu yang berkaitan dengan hal di luar dirinya. ${ }^{9}$

Dari sini sudah jelas kiranya, bahwa kebebasan yang tidak dapat dibatasi seutuhnya ialah kebebesan beragama pada forum internum. Hal ini dikarenakan bersentuhan langsung dengan keyakinan hati dan kecenderungan pikiran. Oleh karenanya tidak mungkin pikiran dapat diadili dan dibatasi. Sebaliknya, pembatasan terhadap kebebasan beragama hanya dapat dilakukan pada forum eksternum, karena hal inilah yang sangat berpotensi bersinggungan dengan hak dan kebebasan beragama orang lain dan bisa menimbulkan gangguan terhadap ketertiban dan kemanan masyarakat. ${ }^{10}$

Kemudian, kalau kita mau menyelami lebih dalam lagi dari dari berbagai terminologi dan penjabaran di atas, maka yang dimaksud kebebasan sesungguhnya adalah ketidakbebasan itu sendiri. Karena tidak satupun perilaku yang bisa dan mampu terbebas dari nilai, norma, dan aturan baik yang bersifat ilahiyah ataupun yang bersifat insaniyah. Adanya aturan ataupun norma adalah sebagai pengikat yang menjadikannya tidak bebas. Artinya, kebebasan itu tidaklah mutlaq (lepas), akan tetapi muqayyad (terbatas). Maka dalam hal ini dibutuhkanlah Negara sebagai penengah di antara melakukan pembatasan sekaligus mengadakan perlindungan berdasarkan undang-undang. Maksud pembatasan di sini bukanlah seperti yang selama ini terjadi-dalam prakteknya digunakan sebagai alat pembenar melakukan kekerasan berbasis agama, melainkan pembatasan pada derajat tertentu manakala kebebasan tersebut mengganggu atau merugikan kebebasan orang lain.

\section{Hate Speech dan Hate Crime sebagai Hal Paling Berbahaya}

Di atas sudah dijelaskan, bahwa menganut suatu keyakinan, kepercayaan, pikiran, dan agama (disebut forum internum) merupakan hak yang tidak dapat dibatasi dalam situasi dan kondisi apapun. Forum internum bersifat absolut karena berada pada internal pikiran

${ }^{8}$ Khanif Al, Hukum dan Kebebasan Beragama Di Indonesia (Yogyakarta: LaksBang Mediatama, 2010), 110.

${ }^{9}$ Hai'ah at-Tahrir, al-Mausu'ah al-Islamiyah al-'Ammah (Kairo: Wazarat al-Awqaf \& al-Majlis al-'Ala li al-Syu,un alIslamiyah, 2001), 536.

${ }^{10} \mathrm{Al}$, Hukum dan Kebebasan Beragama Di Indonesia, 111

Jurnal Kopis: Kajian Penelitian dan Pemikiran Komunikasi Penyiaran Islam

Volume 03, Issue 02, Februari 2021 
manusia mustahil bisa diintervensi dari luar tanpa kesukarelaan secara personal. Sedangkan, manifestasi atau ekspresi (bisa berbentuk tindakan, ritual, dakwah, dan sebagainya) dari keyakinan, kepercayaan, pikiran, dan agama tersebut (disebut forum eksternum) bisa dibatasi dan tidak bersifat absolut.

Salah satu contohnya adalah hate speech. Suatu kebebasan forum eksternum yang digunakan untuk melakukan provokasi yang menganjurkan kebencian atas dasar kebangsaan, ras, ataupun agama yang membentuk suatu hasutan untuk melakukan diskriminasi, permusuhan, bahkan kekerasan. ${ }^{11}$ Hate speech ini merupakan salah satu penyebab paling subtansial berpotensi menimbulkan pertikaian, kerusuhan, bahkan kekerasan yang menjadikan kedamaian, kerukunan, dan keharmonisan antar manusia terkoyak. Nilai fundamen kedamaian islam semakin terlupakan.

Hukum yang mengatur tentang hate speech ini sudah tertuang dalam kovenan hak sipil dan politik (ICCPR) yang telah diratifikasi lewat UU No. 12 tahun 2005, yaitu: "segala advokasi yang menganjurkan kebencian atas dasar kebangsaan, ras atau agama yang membentuk suatu hasutan untuk melakukan diskriminasi, permusuban, atau kekerasan harus dilarang oleb hukum".

Selain bate speech, ada istilah lain yang selalu disandingkan dan diasosiasikan dengannya bila berujung pada suatu kejahatan, yaitu "bate crime". "Hate crime" didefinisikan sebagai suatu kejahatan atau tindak pidana yang dimotivasi oleh suatu kebencian dasar kebangsaan, ras, agama, atau yang lainnya. Unsurnya adalah suatu kejahatan atau tindak pidana (bisa berupa pembunuhan, intimidasi, perusakan barang, serangan, dan sebagainya) dan suatu motif yang bias. Kelompok sasaran yang menjadi korban semata-mata karena mereka merupakan anggota dari suatu kelompok agama atau keyakinan, ras, kebangsaan, kewarganegaraan, atau identitas tertentu lainnya. ${ }^{12}$

Di dalam konteks kebebasan beragama dan berkeyakinan, antara "bate speech" dan "bate crime" sebenarnya merupakan hal yang sangat berbahaya bila dibiarkan. Bukan hanya mengganggu hak kebebasan beragama orang lain, namun juga bisa membatasi, bahkan mendiskriminasi dan mencerabut hak orang lain. Maka, tentu kedua hal ini lah yang kemudian harus dan wajib dibatasi dan diberantas habis sampai keakar-akarnya.

\section{Kewajiban 'Positif'dan Kewajiban 'Negatif' Negara}

Dalam hal hak politik, negara memiliki kewajiban positif untuk menciptakan kondisi dan mendukung semua orang untuk menikmati hak dan kebebasan sepenuhnya. Pada saat yang sama, negara memiliki kewajiban negatif untuk menghormati pelaksanaan hak dan kebebasan individu. Untuk mendukung kewajiban positif, negara harus memaksimalkan semua sumber daya legislatif dan administratifnya. Bahkan Pasal 2 (3) dari "Civil Political Covenant" menyatakan bahwa negara memberikan pemulihan bagi individu yang telah melanggar hak sipil. Restorasi tersebut termasuk litigasi oleh pengadilan untuk memberikan pemulihan bagi korban pelanggaran hak sipil (effective judicial remedy).

${ }^{11}$ Panduan Pemolisian \& Hak Berkeyakinan, Beragama dan Beribadah (Jakarta: KontraS, t.t.), 79.

\footnotetext{
${ }^{12}$ Panduan Pemolisian \& Hak Berkeyakinan, Beragama dan Beribadah, 84.
} 
Konvensi Hak Sipil melarang diskriminasi berdasarkan ras, agama, jenis kelamin dan status lainnya (Pasal 2 (1) Konvensi Hak Sipil). Komite Hak Asasi Manusia Perserikatan Bangsa-Bangsa mendefinisikan diskriminasi sebagai pembedaan, pengecualian, pembatasan atau preferensi, yang mencakup penghapusan atau mengurangi tujuan atau efek kenikmatan dan pelaksanaan hak politik setiap orang. Prinsip non-diskriminasi telah diperluas ke bidang persamaan di depan hukum dan perlindungan hukum yang sama, di mana setiap orang secara efektif dan setara dilindungi dan dilindungi dari praktik-praktik diskriminatif.. ${ }^{13}$

Ketika terjadi pembatasan, diskriminasi, juga kekerasan atas nama agama, maka yang bertanggungjawab penuh adalah Negara dengan kewajiban positifnya. Jika kemudian Negara tidak menjalankan kewajibannya, maka Negara melanggar hak asasi manusia. Ironisnya, sekarang dalam realitas yang terjadi di Indonesia, Kewajiban itu dijalankan oleh negara dengan realisasi terbalik. Dimana, negara yang seharusnya berkewajiban positif, negara malah menjalankan kewajiban negatif, dan begitu pun sebaliknya.

Namun demikian, pembatasan dan pelarangan oleh negara harus dilakukan dengan absah menurut hukum. Tidak bersifat diskriminatif terhadap individu, kelompok, atau identitas tertentu, dan bersifat proporsional sesuai situasi dan kondisi tertentu demi terwujudnya masyarakat yang demokratis dan damai.

\section{Al-Mabadi' Al-Khamsah dan Al-Kulliyah Al-Khams sebagai Prinsip Perdamaian Islam}

Sering kali terjadi dan jarang sekali disadari bahwa mayoritas umat Islam telah lama memiliki pemahaman dikotomi antara Islam dan HAM. Negara-negara dunia ketiga yang mayoritas Muslim sering kali melihat sebelah mata konsep hak asasi manusia. Mereka melihat konsep yang diterapkan Barat tentang HAM hanya sebagai ekspresi yang fokus pada dunia material dan melupakan keberadaan dunia non-material. Konsep hak asasi manusia ini kemudian menjadi sengketa jangka panjang di kalangan umat Islam itu sendiri.

Di kalangan umat Islam sendiri, terdapat persoalan lain yang terkait dengan hak asasi manusia, yakni konsep manusia yang seolah-olah berbeda dengan asumsi dominan perkembangan Barat. Istilah "manusia" dalam hak asasi manusia memang konstruksi Barat dan campuran dari masyarakat Barat, Manusia dianggap sebagai "Promethean" (Promethean), yaitu melawan berbagai otoritas dan menjunjung tinggi otonomi pribadi mutlak Manusia..

Pada saat yang sama, dalam Islam, manusia dianggap sebagai Khalifah, "Wakil Tuhan" atau "Duta Allah", seperti yang dikatakan kitab suci. inni ja'ilun fil ardli khalifah ("Aku akan menciptakan Khalifah di dunia"). Dengan kata lain konsep manusia memiliki keterkaitan yang erat dengan unsur sakral dalam diri manusia, sehingga otonomi tidak mutlak. Manusia bukanlah subjek yang mengatur dirinya sendiri secara positif di hadapan Tuhan. Manusia bukanlah seperti konsep Prometean tentang "pemberontak" terhadap otoritas Tuhan.

${ }^{13}$ Komentar Umum No. 15 dari Konvensi Hak Asasi Manusia tentang mengambil tindakan afirmatif / diskriminasi aktif terhadap kelompok rentan, seperti anak-anak, minoritas dan perempuan, untuk mengurangi atau menghilangkan kondisi yang melanggengkan diskriminasi yang dilarang oleh Kovenan Sipol. Di sini, negara (eksekutif dan legislatif) mengambil langkahlangkah untuk menjamin persamaan pemenuhan hak sipil dan politik.

Jurnal Kopis: Kajian Penelitian dan Pemikiran Komunikasi Penyiaran Islam

Volume 03, Issue 02, Februari 2021 
Sebaliknya menurut Islam, manusia adalah Khalifah yang membangun dunia ini bersama dengan Allah. Dengan demikian, perbedaan struktur masyarakat menyebabkan sebagian umat Islam menolak hak asasi manusia. Masalahnya, pemahaman masyarakat tentang konsep HAM dinilai sudah kebarat-baratan. ${ }^{14}$ Di sini sudah jelas bahwa yang ditolak oleh sebagian umat Islam adalah mengenai konsep manusia bukan pada hak asasinya.

Namun, jika kita mau menyandingkan bukan menentangkan antara Islam dan Barat, maka kita akan menemukan relevansi nilai dalam memandang HAM. Dalam perspektif Islam, hak asasi manusia disebut al-adl (keadilan). Al-adl artinya keseimbangan, harmoni dan selaras. Hakikat Islam adalah menciptakan keadilan dan mendorong umat Islam untuk menegakkan keadilan.

Menurut Said Aqil dalam bukunya Tasawuf Sebagai Kritik Sosial, ia mengatakan adanya titik temu antara HAM dan Islam. Titik temu itu terdapat dalam prinsip al-kulliyah al-khoms (lima prinsip pokok agama) sebagai yurisprudensi Islam: hifdz al-din (perlindungan menganut dan mengamalkan agama); hifdz al-nafs (perlindungan keselamatan jiwa); hifdz al'aql (perlindungan atas nalar); hifdz al-irdh (perlindungan kehormatan); dan hifdz al-nasl wa-l mal (perlindungan kelangsungan keturunan dan harta benda). ${ }^{15}$

Dari kelima prinsip pokok ini, jika dicermati satu persatu, sesungguhnya mencerminkan asas keadilan yang dijunjung tinggi oleh Islam. Di sana terdapat keseimbangan antara kebutuhan individual (misalnya kebebasan berekspresi) dan kebutuhan komunal identitas bersama (misal perlindungan atas agama). Kedua bentuk kebutuhan ini harus selalu seimbang. Menekankan kebebasan individual dan melupakan kebutuhan atas perlindungan atas perlindungan identitas kelompok, jelas menyalahi asas keseimbangan yang dianut Islam. Begitu pun sebaliknya, menekankan identitas kultural untuk "kebutuhan politis" tertentu dan menolak hak individual dengan alasan perlindungan atas identitas tersebut, juga berarti melupakan kenyataan bahwa identitas kelompok itu tidak pernah bisa tetap, tetapi selalu berubah sesuai dengan kebutuhan dan tafsiran yang terus berubah pula pada tingkat individu-individu masyarakat. Bahkan, di dalam Islam sesungguhnya aspek politik (kekuasaan) merupakan sarana untuk mewujudkan kelima hak itu. Bukan malah mencederainya.

Selanjutnya di Indonesia, hak asasi manusia yang didasarkan pada tujuan dasar hukum Islam (maqashid as-syariah) adalah untuk menegakkan hak asasi manusia, yaitu membangun, memelihara, dan mensejahterakan masyarakat. Kepentingan masyarakat itu disebut mashlahah 'ammah. Maka, HAM dalam perspektif Islam diposisikan sebagai salah satu sistem yang diharapkan mampu membawa manusia untuk hidup lebih baik. Yaitu dengan memenuhi kewajiban kemanusiaan dan ketuhanan serta menghargai hak-hak orang lain.

Dengan demikian, Islam sesungguhnya adalah agama manusia, dan untuk kepentingan manusia pula. Dengan penekanan pada dimensi kemanusiaan ini, agama-agama

${ }^{14}$ Said Aqil Siroj, Tasawuf sebagai Kritik Sosial: Mengedepankan Islam sebagai Inspirasi, bukan Aspirasi, Pertama (Bandung: Mizan Pustaka, 2006), 342.

${ }^{15}$ Siroj, 344.

Jurnal Kopis: Kajian Penelitian dan Pemikiran Komunikasi Penyiaran Islam Volume 03, Issue 02, Februari 2021. 
kemudian bisa berinteraksi dengan masalah-masalah demokrasi dan isu-isu Hak Asasi Manusia. Islam, khususnya pesantren mempunyai bahasa yang bagus untuk konvergensi itu, sebagaimana telah dielaborasikan oleh para ulama, al-mabadi' al-khamsah, lima prinsip dasar kemanusiaan. Kelima prinsip tersebut meliputi keadilan ('adalah), persamaan (musawab), musyawarah, tolong menolong (ta'awun) dan kebebasan (al-burriyah). Berbekal al-mabadi'alkhamsah dan al-kulliyah al-khams seperti diuraikan sebelumnya, maka para ulama bisa dengan leluasa berbicara tentang Hak Asasi Manusia dan mendekati problem-problem kemanusiaan universal.

\section{“Toleransi"sebagai Bekal Perdamaian Manusia}

Sesungguhnya Islam adalah anugerah alam semesta (rahmatan lil alamin). Dalam arti, keberadaan Islam telah membawa kedamaian dan terhindar dari segala macam konflik, termasuk konflik vertikal dan horizontal. Itu semua merupakan berkah bagi umat bagi manusia semuanya. Dalam Islam, pemahaman yang benar mengarah pada kebaikan dan selalu lembut. Beberapa kalangan kadang kala bertindak mengatasnamakan Islam hingga menimbulkan konflik horizontal, yang belum tentu menjadi alasan untuk mengutuk Islam. Biasanya pemicu tindakan tersebut antara lain adalah pemahaman yang dangkal atas doktrin-doktrin yang dipegang teguh oleh umat Islam. Ditambah dengan ajaran agama yang dangkal, biasanya mereka mengaku sebagai pemimpin umat dan mewakili sebagian besar masyarakat di Indonesia yang mayoritas muslim.

Intinya, Islam sendiri tidak membedakan penghormatan terhadap setiap orang dari perspektif humanistik. Tidak peduli agama apa yang mereka yakini, selama mereka tidak melawan Islam, perlakuan dan penghormatan mereka akan tetap sama.. Dalam sebuah hadis disebutkan:

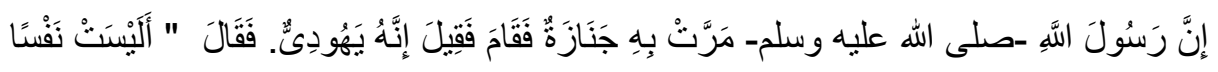

"Sesunggubnya ada jenazab lewat di hadapan Nabi Mubammad Rasulullah SAW, lalu Nabi berdiri menghormatinya. Kemudian, dikatakan padanya: 'jenazah itu adalah orang Yahudi'. Rasul dengan tegas menjawab: 'Bukankah dia juga manusia'." "16

Selain itu, Islam juga mengajarkan tentang sikap persatuan dan toleransi, baik sesama agama maupun antara kelompok agama. Perihal ajaran ini telah menjadi risalah penting dalam sistem teologi Islam yang dibawa oleh Nabi Muhammad SAW. Kebijakan non-paksaan dalam memeluk agama semakin memperkuat bentuk toleransi ini. Allah berfirman dalam Surat al-Baqarah ayat 256:

\section{Terjemah Kemenag:}

Tidak ada paksaan dalam (menganut) agama (Islam). Sungguh, telah jelas jalan yang benar dari jalan yang sesat.

Kutipan ayat di atas menunjukkan bahwa di dalam Agama Islam sendiri tidak memaksa apa pun kepada manusia. Baik yang beragama Islam atau tidak, semuanya tidak ada paksaan. Bahwa di dalam agama tidak memaksa untuk mempercayai kebenaran mutlak, apalagi hanya menurut manusia. Kalimat berikutnya menunjukkan alasan bahwa Allah telah menunjukkan mana yang baik dan mana jalan yang sesat. Tidak hanya itu, dipertegas juga di dalam al-Qur'an Surah al-Ghosiyah ayat 21 yang artinya: "Maka, berilab peringatan karena

${ }^{16}$ Muslim ibn al-Hajjaj, Sahih Muslim (Peace Vision, 1976), 661 Jilid II.

Jurnal Kopis: Kajian Penelitian dan Pemikiran Komunikasi Penyiaran Islam

Volume 03, Issue 02, Februari 2021 
sesungguhnya engkau (Nabi Muhammad) hanyalah pemberi peringatan." Ayat di dalam al-Qu'an tersebut memberi pelajaran bagi umat Islam, bahwa Nabi Muhammad sekalipun tidak diperkenankan memaksa umatnya. Sebab, Nabi Muhammad SAW hanyalah diutus untuk menyampaikan kebenaran dan memberi peringatan atas perintah Allah.

\section{Kesimpulan}

Mencermati Hak Kebebasan Beragama dan Berkeyakinan menjadi suatu yang sangat urgen dalam menciptakan perdamaian. Dalam penegakannya, ternyata akan sangat tergantung pada konstruksi politik hukum dalam suatu negara. Penormaan Hak Asasi Manusia dalam perundang-undangan hanya akan menjadi tulisan di atas kertas bila mana aparatus negara dan oknum pemerintahan masih belum menjalankannya secara serius. Negara mempunyai peranan penting dalam menegakkan Hak Asasi Manusia ini.

Selanjutnya, supaya tercipta suasana yang harmonis di kalangan masyarakat yang plural seperti di Indonesia ini, maka setiap individu muslim harus memiliki kesadaran dan selalu memegang erat nilai-nilai toleransi yang diajarkan dalam Islam. Memberikan contoh akhlak sosial yang menegaskan kepada seluruh manusia bahwa sesungguhnya Islam memang "Rahmatan Lil Alamin".

\section{Daftar Pustaka}

Al, Khanif. Hukum dan Kebebasan Beragama Di Indonesia. Yogyakarta: LaksBang Mediatama, 2010.

Donnelly, Jack. Universal Human Rights in Theory and Practice. Ithaca and London: Cornell University Press, 2013.

Fatia Maulidiyanti. "Catatan Hari HAM 2020: HAM dalam Bayang-Bayang Otoritarianisme." Tahunan. Cahaham 2020. KontraS, 2020.

Hai'ah at-Tahrir. al-Mausu'ah al-Islamiyah al-'Ammah. Kairo: Wazarat al-Awqaf \& al-Majlis al'Ala li al-Syu,un al-Islamiyah, 2001.

Hasibuan, Linda. "Menolak Lupa! Mau Dilantik, Ini Janji Kampanye Jokowi-Amin.” news. Diakses 25 Februari 2021. https://www.cnbcindonesia.com/news/201910200945524-108397/menolak-lupa-mau-dilantik-ini-janji-kampanye-jokowi-amin.

Jufri, Muwaffiq. "Pembatasan terhadap Hak dan Kebebasan Beragama di Indonesia." Jurnal Ilmiah Pendidikan Pancasila dan Kewarganegaraan 1, no. 1 (2016): 40-47.

Media, Kompas Cyber. “Ini Janji Jokowi-JK soal HAM.” KOMPAS.com. Diakses 25 Februari

https://nasional.kompas.com/read/2014/05/21/1630112/Ini.Janji.Jokowi-

JK.soal.HAM.

Muslim ibn al-Hajjaj. Sabih Muslim. Peace Vision, 1976.

Panduan Pemolisian \& Hak Berkeyakinan, Beragama dan Beribadah. Jakarta: KontraS, t.t. 
Republik Indonesia. “Undang-Undang Dasar Tahun 1945.” Lembaran Negara RI, 1945. Perpustakaan Nasional Indonesia.

Sayyidatul Insiyah dan Ismail Hasani. "Regresi Hak Asasi di Tengah Pandemi: Executive Summary Indeks Kinerja HAM Tahun 2020.” Tahunan. Setara Institute, 2020.

Siroj, Said Aqil. Tasawnf sebagai Kritik Sosial: Mengedepankan Islam sebagai Inspirasi, bukan Aspirasi. Pertama. Bandung: Mizan Pustaka, 2006. 